\title{
Transformational Leadership and Employee Motivation in Banking Sector of Pakistan
}

\author{
Adeel Hussain Aunjum ${ }^{1, *}$, Ghulam Abbas ${ }^{2}$, Muhammad Sajid ${ }^{3}$ \\ ${ }^{1}$ COMSATS Institute of Information Technology, Pakistan \\ ${ }^{2}$ Department of Animal Production, Riphah College of Veterinary Sciences, Pakistan \\ ${ }^{3}$ Department of Anatomy, Riphah College of Veterinary Sciences, Pakistan
}

Copyright $\bigcirc 2017$ by authors, all rights reserved. Authors agree that this article remains permanently open access under the terms of the Creative Commons Attribution License 4.0 International License

\begin{abstract}
The intent of the present study is to find out impact of transformational leadership on employee motivation in banking sector of Pakistan. Data about relationship of transformational leadership with employee motivation in banking sector (Allied Bank Limited, Habib Bank Limited and National Bank of Pakistan) was collected through a designed questioner "MLQ (Multi Factor Leadership Questionnaire)". Test size population was 290 components from populace. In actual, 350 polls were sent to populace (Major three banks) and 290 answers were great quality for study and after data screening 270 responses were accounted for of 90 responses of each bank. Regression analysis revealed that all dimensions of Transformational Leadership have positive impact on Employee Motivation which proves that Transformational Leadership has significant, positive and strong effect on employee motivation in the Banking sector of Pakistan. Study also reveal that there is positive and strong relationship of all dimension of transformational leadership such as Idealize Influence (II), Individual Consideration (IC), Intellectual Stimulation (IS) and Inspirational Motivation (IM) with employee motivation. At the end concluded that it is all in the hand of organization to keep the employees motivated to work because they can develop such policies that lead to motivation of employees.
\end{abstract}

Keywords Transformational Leadership, Employee Motivation, Banking Sector of Pakistan, Multi Factor Leadership Questionnaire

\section{Introduction}

World has become a global village and there has been great competition among the organizations. The organizations want to get competitive advantage. The research has proposed that competitive advantage can reaped only through good team work that should be committed to excellence for the success of organization. In literature employee motivation is defined as "The processes that account for an individual's intensity, direction, and persistence of effort towards attaining a goal." There are limited studies those analyzed the transformational leadership effect on employee motivation in banking sector. So this topic needs to be further analyzed. The employee motivation is one of the important elements that are necessary for the success of an organization $[1 ; 2]$. It is necessary for an organization to keep its workers motivated towards work because motivation is considered important for the success of an organization [5]. However, very low literature is found at transformational leadership effect of employee motivation in banking sector. Therefore, this study is going to profound the effects of transformational leadership on employee motivation banking sector. To this reason from claiming consequence about association gather information from, branches, controlling offices \& head offices of significant banks in, Pakistan such as HBL, ABL Also NBP.

The objective of current study is to analyze the degree of association between Transformational leadership and Employee Motivation in banking sector of Pakistan and the impact of Transformational leadership on Employee Motivation in banking sector in Pakistan.

\section{Literature Review}

Transformational leadership has been measured by idealized influence attributed, idealized influence behavioral, inspirational motivation, intellectual stimulation and individual consideration [21; Mohammad et al., 19]. Different statistical tools have been used to reach at the objectives. It has been estimated that transformational leadership has positive and significant impact on employee motivation [9]. Sincerely motivation may be acknowledged as fundamental a component to the achievement about corporate [24]. Introduced study will be likewise identified 
with relationship from maintain transformational heading with manager motivation. In the get from claiming applying specific exact test it is expect that there may be sure. Furthermore motivation can a chance to be proficient through sure conduct technique and it is all in the hand of organization to keep the employees motivated to work by adopting such policies that could lead to motivation of employees [19]. Therefore the present study was designed as an attempt to measure the impact of transformational leadership on employee motivation.

Effect of charismatic leadership on motivation is based on self-concept theory. Actually transformational leadership is very important in field of leadership and research has shown that there is positive correlation between transformational leadership and dependent variable components like performance of the employees, their satisfaction, commitment, and motivation [20].

Various scholars defined motivation in their own words whilst explaining the leadership theory. Motivation may be defined as: desire to do the work, aim, motives and needs etc. The word motivation is extracted from Latin word 'To Move'. Luthans [18] explained motivation as a process of driving the force that is present in human to obtain the desired goals or endeavor that is set in one's mind. According to Luthans [18], there is three basic elements; Needs, Drives and Incentives. However, when there is imbalance that human nature the need of anything is created. To accomplish the needs there is a force that encourages achieving the required satisfaction, so this force is motivation

There is focus on leadership for many years ago for different researchers. Nowadays, attention has been shifted to transformational leadership instead of transactional leadership [5]. Previous researchers about Bass's [5] study were focused of effect of transactional and transformational on effectiveness, satisfaction and performance. Results of that study shows that there is positive relation with stated elements [7]. It also state that it is linked to performance, objectives and quality of innovation [8]. It also studied that there is positive relationship between transactional and stated variables but weaker than transformational leadership.

Bass [8]) explain transformational leaders get higher results as compared to standards due to positive influence on employees. The influence in shape of awareness about importance of outcomes and stimulate employees by encouraging them their self-interest about mission [13]. Rouche et al. [23] state that transformational leadership is quality of leader who influence subordinates beliefs and way of working for completion of organizational goals. Dynamics of transformational leadership includes strong communication with leaders, shared vision and self-interest rewards [15]. Transformational leaders are having subordinates who report greater performance and leaders receive higher rating in return $[10 ; 5]$.

According to Luthans ([18] modern approach is also include transformational leadership theory that is focus point of this study. This study is related to find the impact of transformational leadership on employee motivation in banking sector. This theory is developed by Burns [11] in shape of transactional and transformational. Transactional theory is actually extracted from exchange theory of leadership that is based on relationship between leaders and followers [14]. But on other side transformational theory is depend on transferring beliefs and values to subordinates. Transformational leadership style has their own four dimensions that include Idealize Influence (II), Individual Consideration (IC), Intellectual Stimulation (IS) and Inspirational Motivation (IM).

\section{Dimensions of Transformational leadership}

\section{Idealize Influence}

In this dimension of transformational leadership, leaders provide vision, mission and faith and also inspire subordinates about goals of organization. This worth of leadership makes leader a role model in front of supporters.

\section{Individual Consideration}

Individual Consideration (leader pays attention at individual level) inspires good leaders for coaching and training their followers and encourages them for getting experiences. Individual Consideration makes followers feel very pleased and contented when they are directed individually. They believe capable for achieving desire goals and objectives of the organization that can enable them for credit and rewards. Face to face communication between leader and followers encourage them that are fruitful for working environment. According to Hater \& Bass [15] individual Consideration improve the aptitude of leader to pay more concentration to followers, conveying work assignments to them and feel that they can get more experience by doing this. Employees are stimulated to achieve high level of inspiration for accomplishment of their working needs and act according to direction, so they would like to dedicate time for work due to feelings of discretion and assessment of their capabilities.

\section{Intellectual Stimulation}

Transformational leader make their followers creative and direct their followers to find the solution of problems in rational manner rather than in conventional style. On the other hand this builds followers creative, critical and logical. Leaders imagine that followers have adequate potential for receiving their goals. Well innovative workers get acknowledgment from leaders however they should not be criticized if they do not perform accordingly. According to Hater \& Bass [15] Intellectual stimulation promote 
challenging status and using high level of imagination thus increases the capacity of think in distinctive way and gave new ideas about problem solving and increases the problems solving proficiency.

\section{Inspirational Motivation}

Transformational leader act as role model for the followers by accepting challenges have to face in future thus motivate their workers to accomplish optimum results. They make aware their followers about the vision of organization. Their courage stimulates the subordinates for work and encourages them for being paid more. Followers when encouraged for express some new ideas they freely elaborate their interior feeling and distinctive ideas since they believe that their ideas will be supported (Sosik et al., 1998)

Hypothesis Development

H1: There is Association of Idealized Influence with Employee Motivation in Banking sector in Pakistan.

$\mathrm{H} 2$ : There is Association of Inspiration Motivation with Employee Motivation in Banking sector in Pakistan

H3: There is Association of Intellectual Stimulation with Employee Motivation in Banking sector in Pakistan.

H4: There is Association of Individualized Consideration with Employee Motivation in Banking sector in Pakistan.

\section{Theoretical Model}

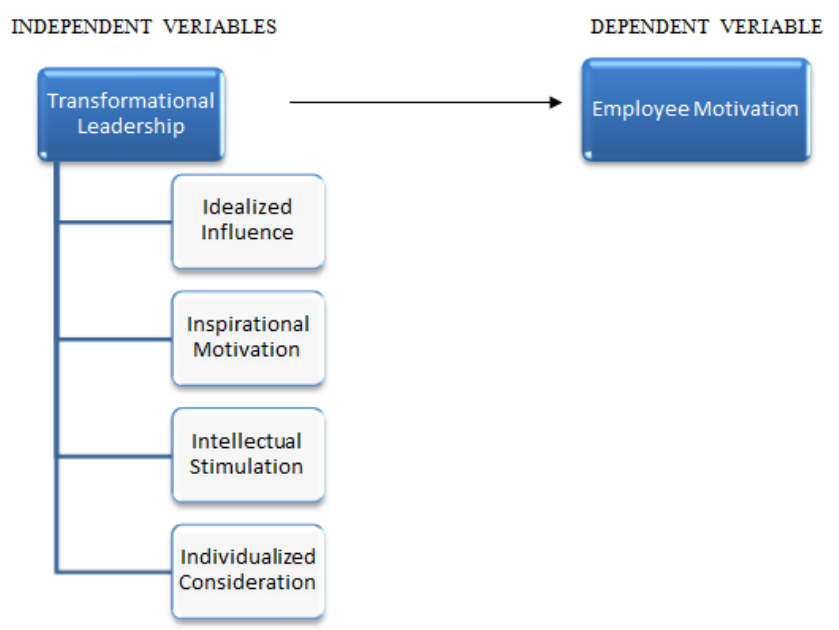

Bass and Avolio model of T.L

\section{Methodology}

The objective of current study is to analyze the degree of association between Transformational leadership and Employee Motivation in banking sector of Pakistan and the impact of Transformational leadership on Employee Motivation in banking sector in Pakistan. For this purpose Questionnaire were adept MLQ (Multi Factor Leadership Questionnaire) by Bass \& Avolio [7].which consist 15 items and 14 items scale developed by Bandura \& Gists [27] and in all items a five point Likert scale was used. Questioner was distributed for the purpose of collecting information in all over Pakistan by implement simple random sampling method. Test size of study was 290 components from populace. Really 350 polls was send to populace (Major three banks)but 290 answers were great quality for study and after data screening 270 responses were accounted for of 90 responses of each bank. For the purpose of statistical findings data was put and investigate through utilizing "Statistical Package of Social Sciences" (SPSS.20)

\section{Results and Discussion}

Leadership is an administrative task, which is generally intended for people, it's a practice of influencing people to attain the goals of the organization $[4 ; 12 ; 16]$. The efficiency of a leader is a major determinant of the success or failure of a group, organization, or even an entire nation. Transformational leadership is a recent approach to leadership that has captured the attention of many researchers in the field of organizational deeds over the past thirty years. The main assertion of the transformational leadership theory is the leader's ability to motivate followers to reach ahead of their potential.

Questionnaires were appropriated to both public and private sectors for getting their responses for study. I have received 228 reactions are male and there rate is $84.4 \%$ and 42 female exposed from 270 , which is $15.6 \%$.In addition to that it is reported in table 160 representatives are in age gathering of 20-25 and its rate in entire populace is 59.3. 80 workers are in gathering of 26-35 and its rate is 29.6 and at the last just 30 representatives are over 36 years. It also demonstrate that the Master level representatives are more than graduate that is 150 and there rate is just $55.6 \%$ of entire sample. I additionally incorporate a section that shows the involvement with present association which demonstrates that 165 workers were encountered among 1- 5 year which is $60.1 \%$ from chose test. 75 workers are contained 6 to 10 years' experience that is $28.8 \%$ of test. Toward the end 30 individuals are identified who have more than 11 years working experience that is just $11.1 \%$. Outcomes show generally workers up to $1-5$ experience.

Transformational leadership not only can improve organizational concert but also can influence workers interest. Leaders have to understand followers' needs, to propose clear visions, to enact good system, and to delegate substantially rage, so followers will make their best effort to the organization and accomplish their own goals. Results of the present study revealed that followers are willing to interact with their leaders because of leader's personality and their kind motivated attitude. This motivates the followers to achieve organizational missions, which play pivotal role to enhance the organizational performance. 
Table 1. Loading Factor by Confirmatory Factor Analysis

\begin{tabular}{|c|c|c|c|c|c|}
\hline \multirow{3}{*}{ Idealize Influence (II) } & $\mathrm{X} 10.778$ & & & & \\
\hline & X2 0.691 & & & & \\
\hline & X3 0.836 & & & & \\
\hline \multirow{3}{*}{ Individual Consideration (IC) } & & X4 0.757 & & & \\
\hline & & X5 0.622 & & & \\
\hline & & X6 0.772 & & & \\
\hline \multirow{3}{*}{ Intellectual Stimulation (IS) } & & & X7 1.655 & & \\
\hline & & & X8 0.762 & & \\
\hline & & & X90.582 & & \\
\hline \multirow[t]{5}{*}{ Inspirational Motivation (IM) } & & & & $\mathrm{X} 102.675$ & \\
\hline & & & & X11 0.901 & \\
\hline & & & & X12 0.682 & \\
\hline & & & & $\mathrm{X} 130.511$ & \\
\hline & & & & $\mathrm{X} 140.231$ & \\
\hline \multirow[t]{14}{*}{ Employee Motivation } & & & & & X16 0.796 \\
\hline & & & & & $\mathrm{X} 170.785$ \\
\hline & & & & & X180.694 \\
\hline & & & & & X190.666 \\
\hline & & & & & $\mathrm{X} 200.743$ \\
\hline & & & & & $\mathrm{X} 210.736$ \\
\hline & & & & & $\mathrm{X} 220.796$ \\
\hline & & & & & $\mathrm{X} 230.794$ \\
\hline & & & & & $\mathrm{X} 240.766$ \\
\hline & & & & & $\mathrm{X} 250.657$ \\
\hline & & & & & $\mathrm{X} 260.745$ \\
\hline & & & & & $\mathrm{X} 270.755$ \\
\hline & & & & & $\mathrm{X} 280.658$ \\
\hline & & & & & X290.836 \\
\hline
\end{tabular}

Source: Statistical Package of Social Sciences:20

Table 1 displays that the developed dimension model in this research by determining each valid estimated indicator with measuring every dimension from the tested concept. The result for every indicator in this model is significant and it can conclude that loading factor for all are accepted and it can be used in this research. The test result by processing data using SPSS.20 can be seen in Fig. 1.

Table 2. Correlation Matrix of Banking Sector

\begin{tabular}{|c|c|c|c|c|c|}
\hline Characteristics & II & IM & IS & IC & EM \\
\hline Idealized Influence & 1 & & & & \\
\hline $\begin{array}{c}\text { Inspirational } \\
\text { Motivation }\end{array}$ & $.474^{* *}$ & 1 & & & \\
\hline $\begin{array}{c}\text { Intellectual } \\
\text { Stimulation }\end{array}$ & $.466^{* *}$ & $.469^{* *}$ & 1 & & \\
\hline $\begin{array}{c}\text { Individualized } \\
\text { Consideration }\end{array}$ & $.473^{* *}$ & $556^{* *}$ & $.455^{* *}$ & 1 & \\
\hline $\begin{array}{c}\text { Employee } \\
\text { Motivation }\end{array}$ & $.501^{* *}$ & $.734^{* *}$ & $.672^{* *}$ & $.633^{* *}$ & 1 \\
\hline
\end{tabular}

Source: Statistical Package of Social Sciences; 20

**Correlation is significant at 0.01 level of significant

It was observed that there is positive and significant (Table
2) correlation between Idealized Influence and Employee Motivation because $\mathrm{r}=.501(\mathrm{P}<0.01)$. Well satisfied and pleased employees are more productive and beneficial for the organization (Saari \& Judge, 2004). Job satisfaction helps to make positive attitudes in staff, boosts up their ethics, improve their performance which resultantly creates respectful affiliation with their coworkers [25].

Inspirational motivation has positive and significant relationship with employee motivation $(\mathrm{r}=0.734, \mathrm{P}<$ 0.01).Intellectual Stimulation also has positive and significant relation with Employee Motivation ( $\mathrm{r}=0.672$ and $\mathrm{P}<.01)$. Individualized Consideration also has positive and significant relation with Employee Motivation $(\mathrm{P}<0.01$, $\mathrm{r}=0.633$ )

Results of the present study support findings of previous studies i.e. Omar [21] concluded that the link of transformational leadership components including individualized consideration, inspirational motivation, idealized influence and intellectual stimulation had a significant positive effect on job satisfaction of employees. Possible association between the discernment of supervisor as a transformative leader, employee satisfaction improves 
and their satisfaction increases when the leaders behave as transformative leaders. The leaders can stimulate followers to challenge their current working conditions, and in turn, followers will perform innovatively and feel satisfied with the organization. In addition, the organization can introduce newly managerial concepts, create a learning opportunity and abide by the organizational regulations to model a spurious organizational culture. The organization can also open a communication channel, respect employees' creativeness, encourage different thinking and brainstorming in order to help employees' to communicate each other and pursue individuals' goal.

Similarly, Mohammad et al. [19] found a statistically significant encouraging relationship existed between the five dimensions of transformational leadership and the two dimensions of job contentment. Furthermore, Shibru and Darshan [24] also found a positive relationship between transformational leadership and subordinate job satisfaction in their studies.

Correlation matrix comprises of the association between the variables. So there is positive and strong (association) relationship between all the dimension of transformational leadership with employee motivation which prove that there is strong and positive association between Transformational leadership and Employee Motivation in banking sector in Pakistan. All variables are positively significant at 0.01 level of significant. Most of the workers in any foundations are volunteers. They do not satisfy with individuals' satisfaction as a goal. Leaders should pay more attention to emphasize the visions of foundations and make a higher contribution to society to satisfy followers.

Table 3. Mean and SD.

\begin{tabular}{|c|c|c|c|c|c|c|}
\hline \multicolumn{2}{|c|}{ Bank Name } & II & IM & IS & IC & EM \\
\hline \multirow{4}{*}{ Total } & Mean & 3.33 & 3.81 & 3.52 & 3.3 & 3.41 \\
\cline { 2 - 7 } & $\mathrm{N}$ & 270 & 270 & 270 & 270 & 270 \\
\cline { 2 - 7 } & $\begin{array}{c}\text { Std. } \\
\text { Deviation }\end{array}$ & 1.02 & 1.158 & 0.878 & 0.81 & 0.915 \\
\hline
\end{tabular}

Source: Statistical Package of Social Sciences; 20

Scoring value of mean of transformational leadership is 3.43 that mean most of the employees of banking sector are adopting "FAIRLY OFTEN" and more in transformational leadership. Dimension IC having low score as compared to other dimensions of transformational leadership.

\section{Results of Regression and Explanation}

Regression Analysis

Following points of research is about the relationship of dimensions of transformational leadership and employee motivation and also between Transformational Leadership and Employee Motivation. There are six tables that show the regression analysis with respective variables.

Regression of Idealized Influence on Employee Motivation

It has come to know that the relationship between employee motivation and through regression analysis by taking employee motivation as dependent variable and as independent variable is positively significant.

Also give here this relationship, in shape of equation

Table 4. Relationship of Idealized Influence on Employee Motivation

\begin{tabular}{|c|c|c|}
\hline \multirow{2}{*}{ Variable } & Employee Motivation & \\
\cline { 2 - 3 } & $\beta$ & $\mathrm{P}$ \\
\hline Idealized Influence & 0.746 & $0.000^{* * *}$ \\
\hline Adjusted R2 & \multicolumn{2}{|c|}{0.59} \\
\hline F value & \multicolumn{2}{|c|}{66.458} \\
\hline $\mathrm{R}$ & \multicolumn{2}{|c|}{0.45} \\
\hline
\end{tabular}

Source: Statistical Package of Social Sciences:20

Dv Employee Motivation

Note: $* \mathrm{P}<0.05,{ }^{*} * \mathrm{P}<0.01,{ }^{*} * * \mathrm{P}<0.001$

Results revealed that $45 \%$ change in employee Motivation was due to the Idealize Influence at the same time as remaining $55 \%$ is the unexplained variability. $R$ value as .59 shows a strong and significant $(\mathrm{F}=66.458, \quad \mathrm{P}<.05)$ relationship between II and EM. Thus, our model is fit. Regression coefficients ( $\beta$ ) of transformational leadership as .74 shows that 1 unit change in II will bring .83 unit changes in overall EM in positive direction.

Institutional/organizational culture just likes soul of the institute which may bring the energy of the organizations. The results of the present study revealed that a support and encouragement for innovational activities and highlighting good work, appreciating and consolidation of staff can improve work efficiency of employees and they feel satisfied with their job. Voonet al. [25] demonstrated a strong relationship between transformational leadership components and job satisfaction similarly Krishnan [17] investigated the transformational leadership components as a key part of high job satisfaction which may increase employee performance during their job.

\section{Regression of Inspirational Motivation on Employee Motivation}

Value of Beta (0.619) for employee motivation indicated 1 percent positive change in Inspirational Motivation bring the $61.9 \%$ positive change in Employee Motivation (Table 5).

Table 5. Relationship between employee motivation and Inspirational Motivation

\begin{tabular}{|c|c|c|}
\hline \multirow{2}{*}{ Variable } & \multicolumn{2}{|c|}{ Employee Motivation } \\
\cline { 2 - 3 } & $\beta$ & $0.000^{* * *}$ \\
\hline $\begin{array}{c}\text { Inspirational } \\
\text { Motivation }\end{array}$ & 0.619 & \multicolumn{2}{|c|}{.69} \\
\hline Adjusted R2 & \multicolumn{2}{|c|}{20.54} \\
\hline F value & \multicolumn{2}{|c|}{.36} \\
\hline $\mathrm{R}$ & \multicolumn{2}{|c|}{} \\
\hline
\end{tabular}

Source: Statistical Package of Social Sciences: 20

Dv Employee Motivation

Note: ${ }^{*} \mathrm{P}<0.05,{ }^{* *} \mathrm{P}<0.01,{ }^{* * *} \mathrm{P}<0.001$ 


\section{Regression of Intellectual Stimulation on Employee Motivation}

Results revealed significant relationship between dependent (employee motivation) and independent variable (Intellectual Stimulation).

Table 6. Relationship between employee motivation and Intellectual stimulation

\begin{tabular}{|c|c|c|}
\hline \multirow{2}{*}{ Variable } & \multicolumn{3}{|c|}{$\begin{array}{c}\text { Employee } \\
\text { Motivation }\end{array}$} \\
\cline { 2 - 3 } & \multicolumn{3}{|c|}{$\mathrm{P}$} \\
\hline $\begin{array}{c}\text { Intellectual } \\
\text { Stimulation }\end{array}$ & 0.69 & $0.000^{* * *}$ \\
\hline Adjusted R2 & \multicolumn{3}{|c|}{25.246} \\
\hline F value & \multicolumn{3}{|c|}{0.40} \\
\hline R & \multicolumn{3}{|c|}{} \\
\hline
\end{tabular}

Source: Statistical Package of Social Sciences: 20

Dv Employee Motivation' Note: ${ }^{*} \mathbf{P}<\mathbf{0 . 0 5}, * * \mathbf{P}<\mathbf{0 . 0 1}, * * * \mathbf{P}<\mathbf{0 . 0 0 1}$

The value of Beta (0.69) revealed a positive(1 unit) increase in intellectual increase .69 in positive change in Employee Motivation.

\section{Regression of Individualized Consideration on Employee Motivation}

Analysis of the results revealed a positive significant relationship (Table 7) between dependent (Employee Motivation) and independent variable (Individualized Consideration)

Table 7. Relationship between employee motivation and Individualized consideration

\begin{tabular}{|c|c|c|}
\hline \multirow{2}{*}{ Variable } & \multicolumn{2}{|c|}{ Employee Motivation } \\
\hline & $\beta$ & $\mathrm{P}$ \\
\hline $\begin{array}{l}\text { Individualized } \\
\text { Consideration }\end{array}$ & 0.83 & $0.000 * * *$ \\
\hline Adjusted R2 & \multicolumn{2}{|c|}{.61} \\
\hline F value & \multicolumn{2}{|c|}{78.257} \\
\hline $\mathrm{R}$ & \multicolumn{2}{|c|}{.37} \\
\hline
\end{tabular}

Source: Statistical Package of Social Sciences: 20

Dv Employee Motivation

Note: $* \mathrm{P}<0.05, * * \mathrm{P}<0.01, * * * \mathrm{P}<0.001$

Findings of the research indicated a $37 \%$ change in employee Motivation due to the Individual consideration at the same time as remaining $63 \%$ is the unexplained variability. $\mathrm{R}$ value as .61 shows a strong and significant $(\mathrm{F}=78.356, \mathrm{P}<.05)$ relationship between II and EM. Thus, our model is fit. Regression coefficients $(\beta)$ of transformational leadership as .83 shows that 1 unit change in II will bring .83 unit changes in overall EM in positive direction.

The results of the present study support the hypothesis and verify that by adopting transformational leadership style, we can produce more satisfaction among the staff and they perform better which may definitely lead organizations towards success. The results of the study also revealed that transformational leadership significantly account for job Motivation. Hence, transformational leaders should exhibit their magnetic leadership, should set a good example, and build a practical and clear vision to their followers. When the followers can feel the satisfaction on the work environment and work itself, they will reflect their satisfactions on the organizational performance. Also, leaders and followers should trust and help each other. Consequently, followers can receive the pleasure from the interpersonal interaction and others confirmation. In the meantime, the study also found that the organizational hierarchy in the foundations is often narrow, and the employees can contact with their supervisors easily during the work. Therefore, the management style of supervisors can greatly influence employees. Moreover, the supervisor in the foundations is often a mission executor and a decision maker. Their behavior can affect the organizational performance strongly.

\section{Findings}

Findings of study as under;

- It can be concluded that employ motivation is a key to success for every organization and employ motivation can be achieved through transformational and charismatic leadership.

- Idealize Influence (II), Individual Consideration (IC), Intellectual Stimulation (IS) and Inspirational Motivation (IM). When all dimension of Transformational Leadership adept by management it leads to higher employee motivation in banking sector in Pakistan.

- It is examined that motivation can a chance to be proficient through sure conduct technique. At last it may be accepted that it is all in the hand of organization to keep the employees motivated to work because they can develop such policies that lead to motivation of employees.

- Employee motivation is strongly effected with dimension of Transformational Leadership i.e.

Only those employee which have developed level of Self efficiency, self-respect, well level of satisfaction and motivation when given Idealize Influence (II), Individual Consideration (IC), Intellectual Stimulation (IS) and Inspirational Motivation (IM).

\section{Conclusions}

From the results of the research, it is concluded that competitive advantage can reaped only through good team work that should be committed to excellence for the success of organization. The employee motivation is one of the important elements that are necessary for the success of an 
organization. It is necessary for an organization to keep its workers motivated towards work because motivation is considered important for the success of an organization. So it is necessary for the corporate to closely monitor this factor. Present study is an attempt to measure the impact of transformational leadership on employee motivation. Actually motivation is considered as an important factor for the success of corporate. The study has used primary data which was collected from the employees of three top commercial banks (Allied Bank, Muslim Commercial Bank and National Bank) of Pakistan. Transformational leadership has been measured by idealized influence attributed, idealized influence behavioral, inspirational motivation, intellectual stimulation and individual consideration. Different statistical tools have been used to reach at the objectives. It has been estimated that transformational leadership has positive and significant impact on employee motivation. So it can be concluded that employ motivation is a key to success for every organization and employ motivation can be achieved through transformational and charismatic leadership.

Sincerely motivation may be acknowledged as fundamental component to the achievement about corporate. Introduced study will be likewise identified with relationship from maintain transformational heading with manager motivation. In the get from claiming applying specific exact test it is expect that there may be sure. Furthermore it is examined that motivation can a chance to be proficient through sure conduct technique. At last it may be accepted that it is all in the hand of organization to keep the employees motivated to work because they can develop such policies that lead to motivation of employees.

\section{Recommendations}

The study suggests following policy recommendations

I Steps should be taken to better the level of idealized influence attributed, idealized influence behavioural, inspirational motivation, intellectual stimulation and individual consideration.

II As transformational leadership has significant positive relationship with employ motivation, so steps should be taken to boost the level of transformational leadership.

III Research should be conducted to find those motives which contribute in making the transformational leadership better and to enhance the level of employ motivation.

IV The organizations should build their research wings for finding and implementation of those factors which contribute in making the level of transformational leadership and employ motivation better.

V Different training centers should be built to enhance the abilities of leadership

\section{REFERENCES}

[1] Albion, M. J. \& n Gagliardi, R. E. (2007). A study of transformational leadership, organizational change and job satisfaction.

[2] Albion, M.J. and R.E. Gagliardi, (2011). A Study of Transformational Leadership, Organizational

[3] Change and Job Satisfaction, Journal of Organizational Change Management, Vol.2, No.1, pp: 23-32.

[4] AL-Hussami, M. (2008). A study of nurses' job satisfaction: the relationship to organizational commitment, perceived organizational support, transactional leadership, transformational leadership, and level of education. European Journal of Scientific Research, Vol.22, No.2, pp286-295.

[5] Bass, B.M. (1985). Leadership and Performance beyond Expectations. New York: Free Press.

[6] Bass, B.M. and Avolio, B.J. (1990). The Implications of Transactional and Transformational

[7] Bass, B.M and Avolio, B.J (1993). Transformational leadership: A response to critiques. In M.M.

[8] Bass, B.M. (1995).Transformational Leadership redux, Leadership Quarterly, 6, 463-78.

[9] Bodla, M.A., and Nawaz, M.M., (2010). Transformational Leadership Style and its relationship with satisfaction, Interdisciplinary Journal of Contemporary Research in Business, Vol.2, No.1,pp 370-381.

[10] Bryman, A. (1993) Charisma and leadership in organizations. London: Sage Publications

[11] Burns, J. M. (1978). Leadership. New York: Harper and Row.

[12] Cummings, G. G., Macgeregor, T., Davey, M., Lee, H., Wong, C. A., Lo, E., Muise, M., \& Stafford, E. (2010). Leadership styles and outcome patterns for the nursing workforce and work environment: A systematic review. International Journal of Nursing Studies, Vol.47, pp 363-385.

[13] Fiedler, F.E. (1996). Research on Leadership Selection and Training: One View of the Future, Administrative Science Quarterly, Vol. 41, pp 241-50.

[14] Gill, A., A.B. Flaschner, C. Shah and I. Bhutani, 2010. The Relations of Transformational Leadership and Empowerment with Employee Job Satisfaction: A Study among Indian Restaurant Employee, Business and Economics Journal, Vol.8, No.2, pp.13-18.

[15] Hater, J.J. and Bass, B.M. (1988).Superiors' Evaluation and Subordinates' Perception of Transformational and Transactional Leadership. Journal of Applied Psychology, Vol. 73, No.4, pp.695-702.

[16] Kennerly, S. M. (1989). Leadership behavior and organizational characteristics: Implications for faculty satisfaction. Journal of Nursing Education, Vol.28, No.5, pp.198-202.

[17] Krishnan, V. R. (2005). Transformational leadership and outcomes: Role of relationship duration. Leadership \& 
Organization Journal, Vol.26, No.5/6, pp.442-457.

[18] Luthans, F. (2007). Organizational Behavior. New York: McGraw-Hill

[19] Mohammad, S.I.S., H.A. Al-Zeaud and E.A.M. Batayneh, 2011. The Relationship between Transformational Leadership and Employee's Satisfaction at Jordanian Private Hospitals, Business and Economic Horizon (BEH), Vol. 5, No.2, pp $35-46$.

[20] Nielsen, K., J. Yarker, R. Randall and F. Munir, 2009. The Mediating Effects of Team and Self-Efficacy on the Relationship between Transformational Leadership and Job Satisfaction and Psychological Well-Being in Healthcare Professionals: A Cross-Sectional Questionnaire Survey, International Journal of Nursing Studies, 4: 1236-1244

[21] Omar, A. (2011). Transformational Leadership and Job Satisfaction: The Moderating Effect of Organizational Trust, LIBERABIT: Lima, Peru, Vol.17, No.2, pp. 129-137 report. Redwood City: Mind Garden

[22] Saari, L. M., \& Judge, T. A., (2004). Employee attitudes and job satisfaction. Human Resource Management, Vol.43, No.4, pp. 395-407.

[23] Rouche, J.E., Baker, G.A. and Rose, R.R. (1989), Shared Vision: Transformational Leadership in American Community Colleges, Community College Press, Washington, DC.

[24] Shibru, B. \& G.M. Darshan, (2011). Effects of Transformational Leadership on Subordinate Job Satisfaction in Leather Companies in Ethiopia. International Journal of Business Management and Skansi, D. Management, 2000, Vol. 5, pp. 51-67.

[25] Voon, M.L., M.C. Lo, K.S. Ngui \& N.B. Ayob, (2011).The Influence of Leadership Styles on Employees' Job Satisfaction in Public Sector Organizations in Malaysia. International Journal of Business, Management and Social Sciences, Vol 2 , No. 1, pp: 24-32

[26] Watson, L. (2009). Leadership's Influence on Job Satisfaction. Journal of Radiologic Technology, Vol.80, No.4, pp. 297-308.

[27] Bandura, A., \& Gist, M. E. 1987. "Self-Efficacy: Implications for Organizational Behavior and Human Resource Management " Academy of Management Review , July 472-85 